\title{
Effect in the quality of intact and minimally processed leaves of collard greens stored at different temperatures
}

\author{
Adriano do N Simões ${ }^{1}$; Mário Puiatti ${ }^{3}$ Luiz CC Salomão ${ }^{3}$; Paulo R Mosquim²; Rolf Puschmann ${ }^{2}$ \\ ${ }^{1}$ UFRPE-Unid. Acad. Serra Talhada, Fazenda Saco, s/n, C. Postal 063, 56900-000, Serra Talhada-PE; ${ }^{2}$ UFV-Depp ${ }^{\text {to. }}$ Biol. Vegetal, 36570- \\ 000 Viçosa-MG; ${ }^{3}$ UFV-Dep ${ }^{\text {to. }}$ Fitotecnia; adriano@uast.ufrpe.br
}

\begin{abstract}
The storage of minimally processed vegetables at low temperatures, in association with proper packaging, represents one of the available technological solutions to mitigate the variations that hinder the quality of final products during storage. We studied the physicochemical variations that occur straight after minimal processing, as well as those that occur during the storage of minimally processed and intact leaves of collard greens (Brassica oleracea var. acephala), stored in 50- $\mu \mathrm{m}$ thick polypropylene bags, with $810-\mu \mathrm{m}$ diameter perforations. Leaves were stored for 15 and 9 days, at 5 and $10 \pm 1^{\circ} \mathrm{C}$, respectively. There were losses of total chlorophyll, soluble sugars, starch, and soluble amino acids immediately after the minimal processing. The rates of degradation and/or use of chlorophyll, ascorbic acid, soluble sugars, and starch during storage were similar on minimally processed and intact leaves, independently of the storage temperature. On contrary, fresh mass loss was almost two fold larger in minimally processed leaves after nine days of storage, regardless of temperature. We also observed a transient increase in the content of soluble amino acids at the end of storage in minimally processed leaves. The increase in the storage temperature to $10^{\circ} \mathrm{C}$ enhanced the chemical variations both in minimally processed and intact leaves. As consequence, the rates of degradation and/or use of chlorophyll, ascorbic acid, sugars and starch mounted, and the accumulation of soluble amino acids was stimulated. We concluded that it is necessary to keep on searching for alternative packaging for minimally processed collard greens, and to associate it with storage at low temperatures, but mimicking distribution and commercialization conditions of the cold-chain. Thus, we can succeed in adequately reducing the physicochemical variations that induce quality losses in minimally processed vegetables.
\end{abstract}

Keywords: Brassica oleraceae var. acephala, minimal processing, shelf life, postharvest.

\section{RESUMO}

Alterações na qualidade de folhas de couve inteiras e minimamente processadas conservadas em diferentes temperaturas

A conservação de hortaliças minimamente processadas em baixas temperaturas, em associação com o uso de embalagens adequadas, continua sendo uma das soluções tecnológicas utilizadas para minimizar ou retardar as mudanças que ocorrem durante a conservação. Foram estudadas as alterações físico-químicas causadas logo após o processamento mínimo e durante a conservação de folhas de couvecomum (Brassica oleracea var. acephala) inteiras e minimamente processadas, mantidas em sacos de polipropileno de $50 \mu \mathrm{m}$ de espessura, com perfurações de $810 \mu \mathrm{m}$ de diâmetro. As folhas foram conservadas por 15 e 9 dias, a 5 e $10 \pm 1^{\circ} \mathrm{C}$, respectivamente. Logo após o processamento mínimo observou-se perda de clorofilas totais, açúcares solúveis, amido e aminoácidos solúveis. As taxas de degradação e/ou utilização da clorofila total, ácido ascórbico, açúcares solúveis e amido durante a conservação das folhas inteiras e minimamente processadas mantidas a $5 \mathrm{e} / \mathrm{ou} 10 \pm 1^{\circ} \mathrm{C}$ foram semelhantes, com exceção para perda de massa fresca e aminoácidos solúveis. As folhas minimamente processadas apresentaram perda de massa fresca quase duas vezes superior às folhas inteiras com nove dias de conservação, independentemente da temperatura. Um aumento transitório no teor de aminoácidos solúveis no final da conservação também foi observado em folhas minimamente processadas. $\mathrm{O}$ aumento da temperatura de conservação para $10^{\circ} \mathrm{C}$ potencializou as alterações químicas tanto em folhas inteiras e minimamente processadas, resultando em elevadas taxas de degradação e/ou utilização de clorofilas, ácido ascórbico, açúcares e amido, além de estimular o acúmulo de aminoácidos solúveis. É necessária a contínua busca de embalagens alternativas àquelas existentes para couve minimamente processada, associado à conservação em baixas temperaturas, para simular as condições de distribuição e comercialização e, assim, minimizar as alterações físico-químicas que reduzem a qualidade do produto final.

Palavras-chave: Brassica oleraceae var. acephala, processamento mínimo, vida útil, pós-colheita.

\section{(Recebido para publicação em 30 de janeiro de 2008; aceito em 21 de maio de 2009) (Received on January 30, 2008; accepted on May 21, 2009)}

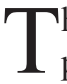
he conservation of minimally processed vegetables at low temperatures associated with adequate packaging, remains as one of the technological solutions to mitigate or delay the physicochemical, biochemical, physiological, and microbiological decay that takes place during storage (Rico et al., 2007). In the past decade, research on vegetable minimal processing is achieving major technological and scientific advances in Brazil (Puschmann et al., 2008). However, minimally processed vegetables continue to be sold under unsatisfactory conditions, such as temperatures around $10^{\circ} \mathrm{C}$ in supermarket shelves. Minimally processed collard greens, when kept in polypropylene bags, produce an unpleasant smell in the first days after opening the packaging (Teles, 2001). In addition, minimally processed collard greens have both the respiration and ethylene synthesis transiently enhanced (Carnelossi et al., 2005), and undergo also variations of chemical nature, such as vitamin $\mathrm{C}$ and total 
chlorophyll losses (Carnelossi, 2000). It is known that Cryovac $^{\circledR}$ (PD 941) is the most suitable packaging for minimally processed collard greens (Carnelossi et al., 2005). However, Cryovac ${ }^{\circledR}$ films are relatively expensive, which makes price of the final product even higher. An alternative packaging for minimally processed collard greens, cheaper than Cryovac $^{\circledR}$ films, but still appropriate, are the microperforated polypropylene bags, similar to the polypropylene with oriented microperforations, which is in use by European processing companies in Spain, England, and Ireland for leafy vegetables and mixed vegetable salads (Varoquauz \& Mazollier, 2002; Al-Ati \& Hotchkiss, 2002). However, microperforated packaging has been having little use in minimally processed vegetables in Brazil.

Several studies were used as basis to draw flowcharts of minimal processing, as well as for the optimization of storage conditions (Carnelossi, 2000; Teles, 2001). However, the continuous search for alternative packaging is always relevant due to the applicability to the industry. Moreover, the assessment of other variations in the physicochemical properties that may occur immediately after the minimal processing of collard greens, as well as those that take place in the medium and long term during storage, at suitable and not suitable temperatures, may bring to light additional knowledge to study quality in collard greens. It is expected that the physicochemical changes that occur soon after the minimal processing of collard greens will not progress if the product is stored at $5^{\circ} \mathrm{C}$.

Therefore, the aim of this study was to assess the physicochemical variations that happen instantly after the minimal processing of collard greens, as well as along the storage period, and use them as tools to evaluate the quality of the final product.

\section{MATERIAL AND METHODS}

Plants of collard greens (Brassica oleracea var. acephala) accession BGH 1578, which correspond to the Portuguese variety, were grown in the experimental garden of the Universidade Federal de Viçosa, Minas Gerais State, Brazil (2045'14' S, 42 $\left.{ }^{\circ} 52^{\prime} 53^{\prime \prime} \mathrm{W}\right)$. Leaves were harvested when $35 \mathrm{~cm}$ long and brought instantly to the laboratory. Petioles were immersed in containers filled with tap water for 24 hours, at $5 \pm 1^{\circ} \mathrm{C}$ (Carnelossi, 2000). Following, a number of leaves were minimally processed, while the others remained intact.

The minimal processing was performed according to Carnelossi et al. (2005), in approximately one hour, at $18 \pm 2^{\circ} \mathrm{C}$. Next, the minimally processed leaves, as well as those that remained intact, were packed in respectively $22 \times 26 \mathrm{~cm}$ and $39 \times 26 \mathrm{~cm}$ (length $\mathrm{x}$ width) polypropylene bags. In both cases, bags were $50 \mu \mathrm{m}$ thick and had 648 holes $(810 \mu \mathrm{m}$ in diameter). In the bags in which intact leaves were placed, holes were located at the petiole ends. Each package contained four leaves, which corresponded to 100 and $200 \mathrm{~g}$ of minimally processed and intact leaves respectively.

Packages were sealed with the commercial sealer Selamut, R. Baião, and placed in a display with forced air ventilation, protected from light, at 5 and $10 \pm 1^{\circ} \mathrm{C}, 90 \pm 5 \%$ relative humidity, up to 15 and 9 days, respectively for each temperature. We evaluated the leaves every other day until the sixth day, and then in three-day intervals. The following characteristics were assessed: (a) Fresh mass: obtained by gravimetry in a scale with 0.5 $\mathrm{g}$ precision. The loss of fresh mass corresponded to the difference between the fresh mass in each evaluation date and in the beginning of the storage; (b) Total chlorophyll content: determined according to Lichtenthaler (1987). Leaf discs of $200 \mathrm{mg}$ for the intact leaves or leaf slices for the minimally processed product were mixed with $0.2 \mathrm{~g}$ of calcium carbonate and acetone $(80 \%)$. The extract was centrifuged (Sorvall RT 6000-D) at $6000 \mathrm{rpm}$, for 10 minutes, at $10^{\circ} \mathrm{C}$. Next, the supernatant volume was adjusted to $25 \mathrm{~mL}$ with acetone $(80 \%)$. Samples were protected from white light and the absorbance readings were carried out at 646.8 and $663.2 \mathrm{~nm}$; (c) Vitamin $\mathrm{C}$ : determined according to the American Official Analysis of Chemistry (AOAC, 39,051), with the adaptations proposed by Carnelossi (2000); (d) Contents of soluble sugars, starch, and soluble amino acids: assessed by immersion of $1 \mathrm{~g}$ of leaf blade discs in $6 \mathrm{~mL}$ of ethanol $80 \%$, at $80^{\circ} \mathrm{C}$, followed by grinding in a mortar with washed sand. The extract was homogenized and centrifuged at $2000 \mathrm{~g}$, for 10 minutes. The precipitate was resuspended three times in $5 \mathrm{~mL}$ of ethanol $80 \%$, at $80^{\circ} \mathrm{C}$. The supernatants were combined and the volume was adjusted to $25 \mathrm{~mL}$ to make the ethanol extract I. The ethanol extract II was obtained by removing pigments and lipids from a $10 \mathrm{~mL}$ aliquot from the ethanol extract I, using a separating funnel and adding $10 \mathrm{~mL}$ of chloroform and $10 \mathrm{~mL}$ of distilled water. The aqueous phase was evaporated at $45^{\circ} \mathrm{C}$ in a rotary evaporator, under vacuum. The residue was resuspended with $2 \mathrm{~mL}$ of distilled water for the determination of soluble sugars and amino acids. The precipitate that resulted from the centrifugation after the ethanol extraction was used to evaluate the starch content according to the methodology described by McCready et al. (1950), adapted to coffee leaves by Patel (1970).

The total soluble sugars and the starch were quantified using the Antrona method (Disch, 1962). For starch, the results were multiplied by a factor of 0.9 . The content of soluble amino acids was determined according to Moore \& Stein (1948), employing the ethanol extract II. A $20 \mu \mathrm{L}$ aliquot of the ethanol extract II were added to the reaction medium containing $1.5 \mathrm{~mL}$ of ninhydrin and $180 \mu \mathrm{L}$ of citrate buffer, pH 5.0 (200 mM). The samples were boiled for 20 minutes and, after cooling, $8 \mathrm{~mL}$ of $80 \%$ ethanol were added, under stirring, to reach a final volume of 11.5 $\mathrm{mL}$. After a 10-minute rest, the readings were carried out in a spectrophotometer (Model U-2000 Hitachi), at $570 \mathrm{~nm}$. A mix of $0.25 \mathrm{mM}$ glycine, $0.25 \mathrm{mM}$ glutamic acid, $0.25 \mathrm{mM}$ phenylalanine, and $0.25 \mathrm{mM}$ arginine, were used as standard. Ninhydrin was prepared using $32 \mathrm{mg}$ of $\mathrm{SnCl}_{2} 2 \mathrm{H}_{2} \mathrm{O}$, dissolved in 20 $\mathrm{mL}$ of $0.2 \mathrm{M}$ citrate buffer, $\mathrm{pH} 5.0$. Following, $20 \mathrm{~mL}$ of ethylene glycol monomethyl ether were added into $0.8 \mathrm{~g}$ 
of the dissolved ninhydrin. After mixing, the final volume was completed to 100 $\mathrm{mL}$ with distilled water.

We used a completely randomized design for each storage temperature, in a split plot scheme, where types of leaves (intact and minimally processed) were assigned to the plots, and evaluation dates $(0,2,4,6,9,12$, and 15 days after the beginning of the storage), to the subplots, with three replications. Data were submitted to the analysis of variance, using the software SAEG 5, from the Central Data Processing of UFV.

\section{RESULTS AND DISCUSSION}

Fresh mass loss in leaves increased with the storage period (Figure 1). However, the storage temperature did not influence the loss progress, as also observed by Shim et al. (2007). Higher loss rates in fresh mass were observed in minimally processed than in intact leaves (Figure 1), probably due to the increase in the evaporation surface when leaves were chopped for the minimal processing. In addition, tissues are structurally modified when cut: the cells that become exposed do not have specialized components such as cutin, like the epidermal cells, which remain undamaged in intact leaves (Amarante, 1991). Thus, processed tissues are subjected to severe dehydration during storage (Simões et al., 2010).

Dehydration is a physical response that leads to critical difficulties during the storage of minimally processed products, such as whitening in carrots (Simões et al., 2010) and beets (Vitti et al., 2004). This results in an oldish and unattractive visual aspect. In the case of minimally processed collard greens, this symptom was not observed, unlike the turgor loss, which was promptly noticeable after opening the package. Fresh mass loss was close to $10 \%$ after nine days of storage, at both 5 and $10^{\circ} \mathrm{C}$ (Figure 1). Intact leaves were clearly wilted, even within the sealed packages and especially after nine days of storage, when the fresh mass loss was close to $4 \%$, at both 5 and $10^{\circ} \mathrm{C}$ (Figure 1).

The perforations in the packaging probably worsened the fresh mass

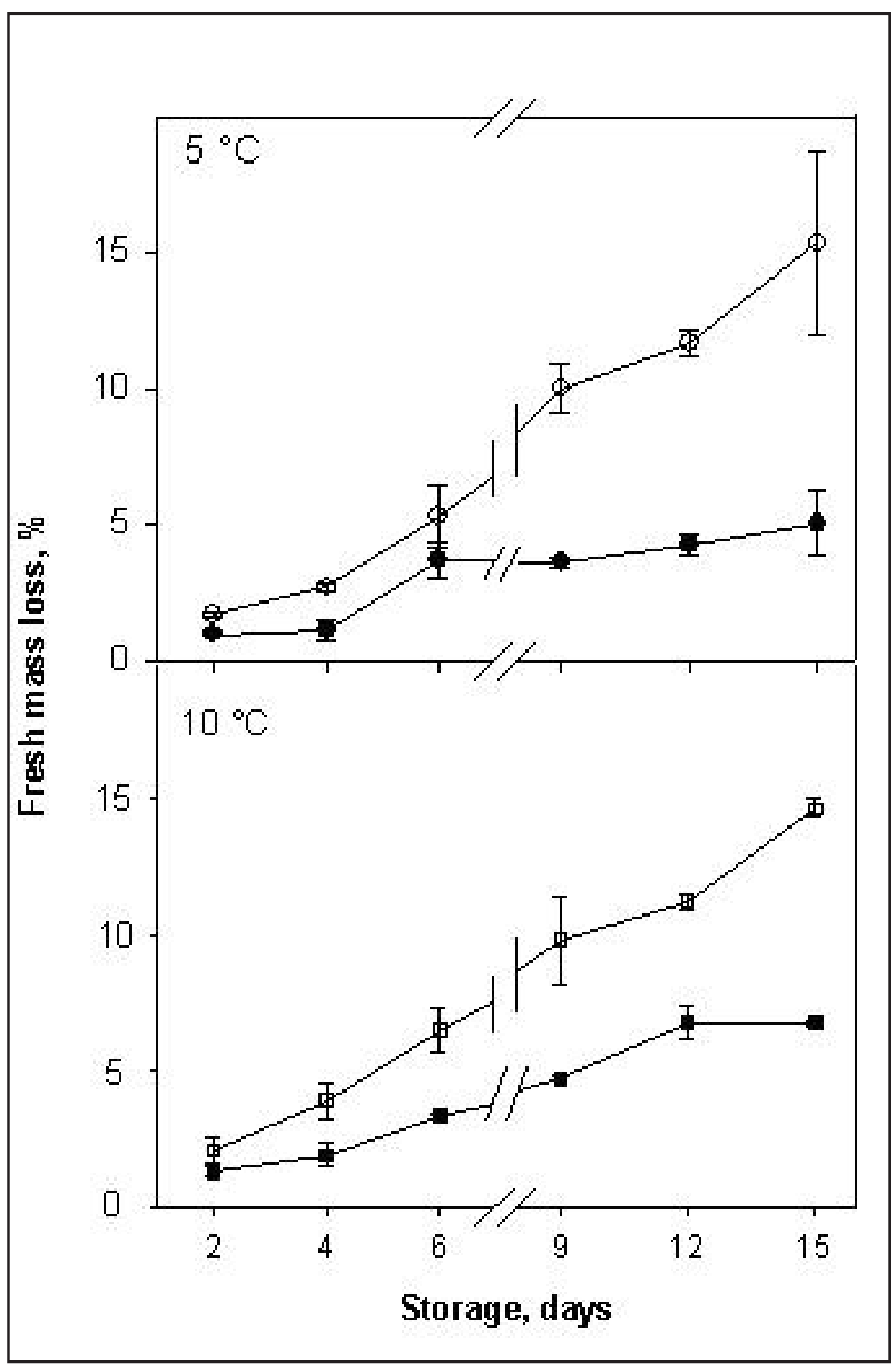

Figure 1. Fresh mass loss on intact $(\bullet / \mathbf{\bullet})$ and minimally processed leaves $(\mathrm{O} / \square)$ of collard greens, stored at 5 and $10^{\circ} \mathrm{C}$ (perda de massa fresca em folhas de couve inteiras $(\bullet / \mathbf{\bullet})$ e minimamente processadas (O/ロ), mantidas a 5 e $\left.10^{\circ} \mathrm{C}\right)$. Viçosa, UFV, 2007.

${ }^{*}$ Vertical bars represent the means standard error, $n=3$ (as barras verticais representam o erro padrão da media, $\mathrm{n}=3$ ).

loss both in minimally processed and in intact leaves. This occurs because the pores reduce the resistance to the diffusion of water vapor through the film. So, to minimally processed collard greens is very important to go on studying alternative polypropylene films, as well as searching for the ideal number of perforations.
The initial content of total chlorophyll was lower in minimally processed leaves right after processing than in the leaves that remained intact $(\mathrm{p}<0.05)$ (Figure 2). The slicing, coupled with immersion in water and rinsing during sanitation, probably accounted for such difference. In the first rinse, the residual water became deeply pigmented after 


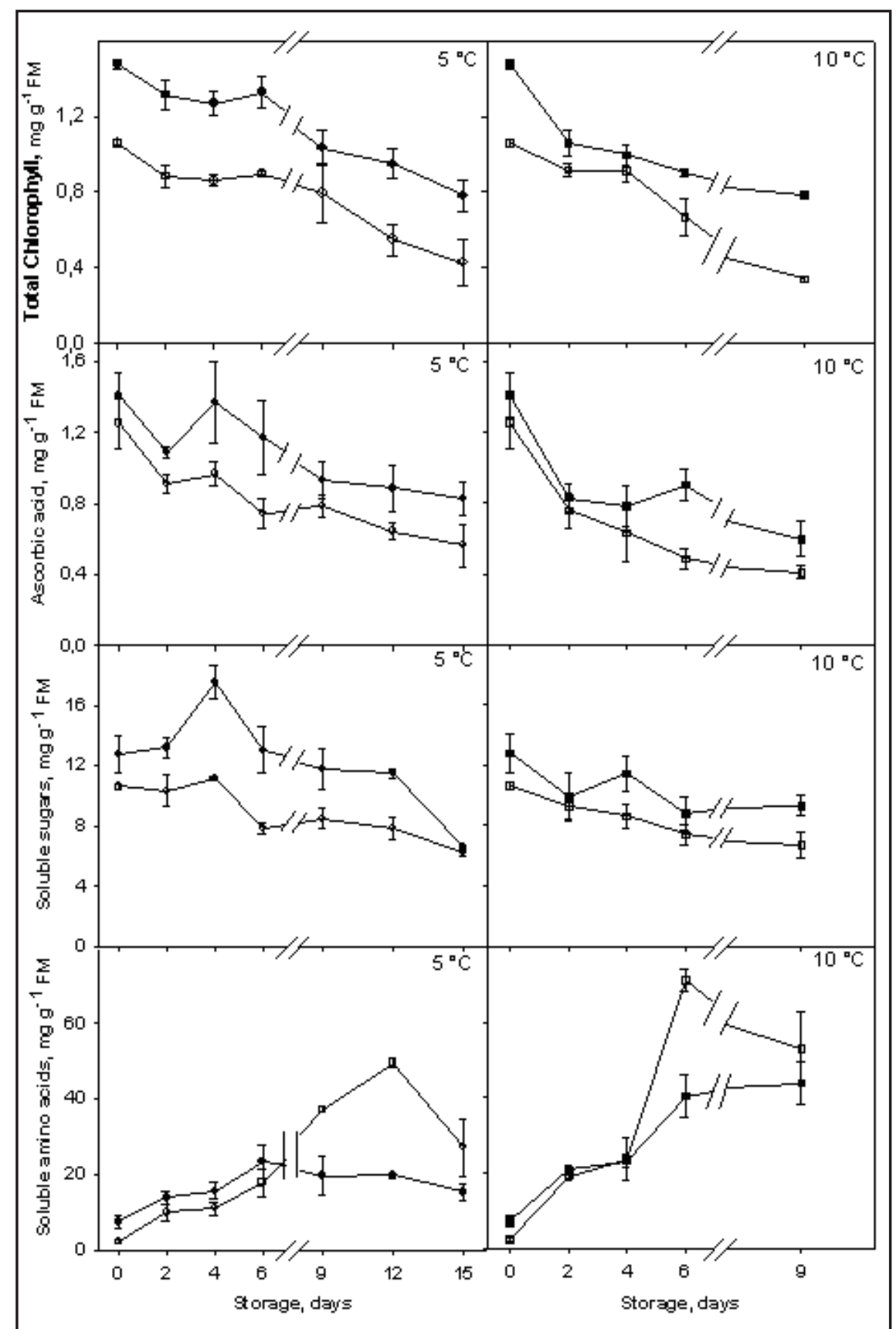

Figure 2. Contents of total chlorophyll, ascorbic acid, soluble sugars, and soluble amino acids in intact $(\bullet / \square)$ and minimally processed leaves of collard greens $(\mathrm{O} / \square)$, stored at 5 and $10^{\circ} \mathrm{C}$ (clorofilas totais, ácido ascórbico, açúcares solúveis e aminoácidos solúveis em folhas de couve inteiras $(\bullet / \square)$ e minimamente processadas $(\mathrm{O} / \square)$, mantidas a 5 e $\left.10^{\circ} \mathrm{C}\right)$. Viçosa, UFV, 2007.

${ }^{*}$ Vertical bars represent the means standard error, $n=3$ (as barras verticais representam o erro padrão da media, $n=3$ ).

immersing the chopped leaves, while the residual solution from the sanitation and final rinse was only faintly stained (data not shown). The variations in the total chlorophyll content of non-injured tissues that were adjacent to the cut and the pigmentation observed in the residual water as consequence of the processing instantaneous loss of the cellular content occurred only in cells that were cut or injured during chopping. Tissues adjacent to the cut, proportionally in much larger amount than injured tissues, kept their initial characteristics.

Minimally processed and intact leaves had similar losses of total chlorophyll during storage, close to 38 and $29 \%$ when kept at 10 and $5^{\circ} \mathrm{C}$, for six and nine days, respectively (Figure 2). This behavior could be followed by the naked eye by observing leaf yellowing. Moreover, minimally processed leaves showed signs of browning, especially in areas closer to the cut, as also reported in minimally processed lettuce (Ke \& Saltveit, 1989). In our study, the rate of chlorophyll degradation in minimally processed and intact leaves was speeded up in $10^{\circ} \mathrm{C}$, very likely because of the higher enzyme activity at this temperature, particularly enzymes that degrade chlorophyll (Matile et al., 1996) and those involved in senescence (Maragoni \& Heaton, 1996). Tulio et al. (2002) observed the same in stored jute leaves. These results strengthen the usual recommendation: the use of low temperatures during storage reduces the losses caused by minimal processing (Rico et al., 2007, Simões et al., 2007). We could conclude also that the minimal processing led to significant chlorophyll leakage. However, during storage, minimally processed and intact leaves had similar rates of chlorophyll degradation and/or use.

There were no ascorbic acid significant losses $(\mathrm{p}<0.05)$ in minimally processed leaves when compared to intact leaves (Figure 2). We believe that, depending on the tissue and also on the handling during processing, it is possible to preserve the initial ascorbic acid levels. Drops in the ascorbic acid contents as consequence of minimal processing indeed occur, as observed in cabbage (Simões et al., 2007). Contrary to what was observed in the beginning of the experiment, there was a marked decrease in ascorbic acid contents during storage, both in minimally processed and intact leaves, at both temperatures (Figure 2). Nevertheless, it should be highlighted that the rate of loss was much lower at $5^{\circ} \mathrm{C}$, independently of 
processing or keeping leaves intact (Figure 2). Therefore, the influence of temperature over the ascorbic acid content was more pronounced than that caused by the minimal processing.

A recent study associated ascorbic acid with protection against enzymatic browning in rocket leaves (Del'Innocent et al., 2007). The same might happen in collard greens, due to its high ascorbic acid content (Figure 2). In our work, we observed a strengthening of the enzymatic browning only when the ascorbic acid and the chlorophyll contents dropped (Figure 2), and leaves started showing chlorosis (Simões, 2004). The ascorbic acid role in $o$-quinone reduction and in the inhibition of the catalytic action of polyphenol oxidase is known (Walker, 1977; Saper, 1993). However, studies that show the possible involvement of the ascorbic acid on the tolerance to darkening in chopped vegetal tissues are still lacking. The current results indicated that the storage temperature influenced the ascorbic acid content, a nutritional and functional attribute of quality (Reyes et al., 2007). On contrary, minimal processing did not affect the ascorbic acid content, since the losses were similar in minimal processed and intact leaves.

There was a significant decrease $(\mathrm{p}<0.05)$ on soluble sugars (Figure 2) and starch (data not shown) contents in minimally processed in relation to intact leaves. Moreover, we noticed that storage enhanced the degradation and/or use of sugars in both minimally processed and intact leaves (Figure 2). Probably, the perforations in the bags allow the diffusion of high $\mathrm{O}_{2}$ levels inside the package, resulting in an intense respiration and, thus, inducing the use of substrates such as sugars. On the other hand, minimum processing did not significantly speed up the rate of degradation and/or use of these substrates in relation to what was observed in intact leaves.

The contents of soluble amino acids increased during storage (Figure 2), particularly in the minimally processed leaves kept at $10^{\circ} \mathrm{C}$, reaching the peak after six days of storage. Minimally processed leaves stored at $5^{\circ} \mathrm{C}$ showed the highest contents of soluble amino acids only after twelve days (Figure 2). Therefore, the contents of amino acids were significantly influenced by the storage temperature and processing, resulting in the differential accumulation of soluble amino acids observed in the leaves. The increase in the amino acids content can be attributed to protein degradation in association with the beginning of leaf senescence (Backer 1987; Tulio et al., 2002). At this point, the rate of protein degradation and/or use is higher than the rate of synthesis. In addition, it is likely that proteases were much more active in minimally processed than in intact leaves (Martin, 1972a, b; Kays, 1991b).

In general, we found that the immediate chemical changes in the leaves induced by the minimal processing, such as loss of total chlorophyll, total soluble sugars, starch, and soluble amino acids, did not hinder the quality of the final product in collard greens. Throughout storage, the rate of degradation and/ or use of these nutrients was similar in minimally processed and intact leaves, expect for fresh mass loss and soluble amino acids. These results indicate that, although the minimal processing causes an immediate loss of some nutrients, the storage at low temperatures is crucial to mitigate the chemical variations that take place at mid term, and consequently, to keep the quality of minimally processed collard greens.

Finally, we believe that the perforated packaging may have stimulated the physicochemical variations we observed, resulting in dehydration, yellowing, and enzymatic browning, probably due to the high polyphenol oxidase activity (Simões et al., 2007). Hence, we must go on searching for alternative packaging for minimally processed collard greens to replace those currently available for the market. Additionally, the use of suitable packaging should be associated to storage at low temperatures. This is the most promising approach to succeed in keeping the physicochemical variations involved in quality loss of minimally processed products at low levels.

\section{ACKNOWLEDGEMENTS}

We would like to thank the Foundation for Research Support of the State of Minas Gerais (FAPEMIG), Coordination of Improvement of Higher Educational Personnel (CAPES) and The National Council for Scientific and Technological Development (CNPq) for partially financing this work.

\section{REFERENCES}

AL-ATI TAREQ; HOTCHKISS JH. 2002. Application of packaging modified atmosphere the fresh-cut fruits and vegetables. In: FreshCut Fruits and Vegetables, Science, Technology and Market. New York: CRC Press. 467p.

AMARANTE CVT. 1991. Relação entre horário de colheita e senescência em folhas de couve (Brassica oleracea L. acephala). Viçosa: UFV. $65 \mathrm{p}$ (Tese mestrado).

CARNELOSSI MAG. 2000. Fisiologia póscolheita de couve (Brassica oleracea var. acephala) minimamente processada. Viçosa: UFV. 81p (Tese doutorado).

CARNELOSSI MAG; SILVA EO; CAMPOS RS; PUSCHMANN R. 2005. Respostas fisiológicas de folhas de couve minimamente processadas. Horticultura Brasileira 23: 215-220.

BACKER AV. 1987. Amino acids and nitrogenous compounds. In: WEICHMANN J. (ed). Postharvest Physiology of Vegetables. Dublin: Marcel Dekker. p. 475-480.

DEL'INNOCENTI E; PARDOSSI A; TOGNONI F; GUIDI L. 2007. Physiological basis of sensitivity to enzymatic browning in 'lettuce', 'escarole' and 'rocket' salad when stored as fresh-cut products. Food Chemistry 104: 209-215.

DISCHIE Z. 1962. Color reaction of carbohydrates. In: WHISTLER RL; WOLFRAN ML. Methods in carbohydrates chemistry. New York: Academic Press. 1: 477-512.

HEATON JW; MARAGONI AG. 1996. Chlorophyll degradation in processed foods and senescent plant tissue. Trends of Food Science Technology 7: 8-15.

KAYS JS. 1991b. Postharvest Physiology of Perishable Plant Products. New York: AVI Book, Van Nostrald. p. 335-408.

KE D; SALTVEIT ME. 1989. Wound-induced ethylene production, phenolics metabolism and susceptibility to russet spotting in iceberg lettuce. Physiology Plantarum 76: 412-418.

LICHTHENTHALER HK. 1987. Chlorophylls and carotenoids: pigments of photosynthetic biomembranes. In: PACKER L; DOUCE R (eds.) Methods of Enzimology 148: 350-382.

MARTIN C; THIMAN KV. 1972. The role of protein synthesis in the senescence of leaves. I. The formation of proteases. Plant Physiology 49: 64-71.

MARTIN C; THIMAN KV. 1973. The role of protein synthesis in the senescence of leaves. II. The influence of amino acids on senescence. Plant Physiology 50: 432-437.

MATILE P; HORTENSTEINER S; THOMAS H; 
KRAUTLER B. 1996. Chlorophyll breakdown in senescent leaves. Plant Physiology. 112: 1043-9.

MCCREADY RM; GUGGOLZ J; SILVEIRA V; QWENS H S. 1950. Determination of starch and amylase in vegetables. Annals of Chemical 22: 1156-1158.

MOORE S; STEIN WH. 1948. Photometric ninhydrin method for use in chromatrography of amino acids. Journal of Biological Chemistry 176: 367-388.

PATEL RZ. 1970. A note on the seasonal variations in starch content of different parts of Arabica coffee trees. East African Agriculture Eor Journal 36: 1-4.

PUSCHMANN R; SIMÕES AN; COSTA FB; MELO AAM; NEVES ATG; MARQUES CS; DINIZ LT; JUNQUEIRA MS; COLLETA CLD. 2008. Histórico do processamento mínimo no Brasil. VEncontro Nacional Sobre Processamento de Frutas e Hortaliças, 8 a 11 de Abril, 21-27, Lavras: Editora UFLA.

REYES LF; VILLAREAL E; CISNEROSZEVALLOS L. 2007. The increase in antioxidant capacity after wounding depends on the type of fruit or vegetables tissue. Food Chemistry 101: 1254-1262.

RICO D; MARTÍN-DIANA AB; BARAT JM;
BARRY-RYAN C. 2007. Extending and measuring the quality of fresh-cut fruit and vegetables: a review. Trends in Food Science \& Technology 18: 373-386.

SAPERS GM. 1993. Browning of foods: control by sulphites, antioxidants, and other means. Food Technology 47: 75-84.

SHIN Y; LIU RH; NOCK JF; HOLLIDAY D; WATKINS CB. 2007. Temperature and relative humidity effects on quality, total ascorbic acid, phonetics and flavorous concentrations, and antioxidant activity of strawberry. Postharvest Biology and Technology 45: 349-357.

SILVA VA. 2003. Fisiologia de cenoura minimamente processada. Viçosa: UFV. 78p (Tese mestrado).

SIMÕES AN. 2004. Alterações químicas e atividade de enzimas em folhas de couve inteira e minimamente processadas. Viçosa: UFV. 74 p (Tese mestrado).

SIMÕES AN; COSTA FB; SILVA EO; PUSCHMANN R. 2007. Estratégias para reduzir o estresse do processamento mínimo. Visão Agrícola: Pós-colheita de Frutas e Hortaliças. 7.

SIMÕES AN; VENTRELLA MC; MORETTI CL; CARNELOSSI, MAG; PUSCHMANN R. 2010. Anatomical and physiological evidence of white blush baby carrot surfaces. Postharvest Biology and Technology 55: 45-52.

TELES CS. 2001. Avaliação física, química e sensorial de couve (Brassica oleraceae, L. var acephala) minimamente processada, armazenada sob atmosfera modificada. Viçosa: UFV. 103p (Tese mestrado)

TULIO AZ; OSE JR; CHANCHIN K; UEDA Y. 2002. Effects of temperatures on postharvest quality of jute leaves (Corchorus olitorius L.). Postharvest Biology and Technology 26: 329-338.

VITTI MCD; KLUGE RA; GALLO RC; MORETTI CL; JACOMINO AP. 2004. Efeito do momento de sanitização sobre atributos físico-químicos e microbiológicos de beterraba minimamente processadas. Horticultura Brasileira 22: 718-721.

VOROQUAUX P; GOUBLE B; DUCAMP MARIE-NOELLE; SELF G. 2002. Procedure to optimize modified atmosphere packaging for fruit. Fruits 57: 313-322.

WALKER JRL. 1977. Enzymatic browning in foods, its chemistry and control. Food Technology New Zealand 12: 19-25. 